\title{
Ermelo weeping lovegrass response to clipping, fertiliza- tion, and watering
}

\author{
ROBERT A. MASTERS AND CARLTON M. BRITTON
}

\section{Abstract}

A management strategy using short-duration grazing and fertilization was simulated in a study with individual 'Ermelo' weeping lovegrass [Eragrostis curvula (Shrad.) Nees] plants. Influence of 2 levels of clipping [unclipped during the growing season and clipped (C) to $10-\mathrm{cm}$ stubble height each time regrowth reached $40 \mathrm{~cm}$; fertilizer [unfertilized and 70-34-44 kg N-P-K/ha (F)]; and watering frequency [irrigated to field capacity at 7- (WET) and 14(DRY) day intervals] on cumulative herbage dry matter yield, crude protein yield, and water-use efficiency, and root mass of individual weeping lovegrass plants grown in soil contained in polyethylene tubes was determined. Clipping combined with fertilization improved herbage dry matter yield and water-use efficiency. Fertilized plants yielded at least $5.4 \mathrm{~g}$ crude protein/tube as compared to less than $2.0 \mathrm{~g}$ crude protein/tube produced by unfertilized plants. Between 1 June and 15 September 1983 WET-Ftreated plants provided sufficient regrowth for 5 harvest events with an average of 24-day intervals between harvests. In contrast, regrowth of WET-, DRY-F, and DRY-treated plants was harvested 3 times with intervals between harvests averaging between 32 and 35 days. Clipping had no effect on root mass of WET-, DRYF-, and DRY-treated plants, but reduced root mass of WET-Ftreated plants by $\mathbf{4 4 \%}$. Based on this simulation of a forage management strategy, periodic harvest of weeping lovegrass combined with fertilization improved herbage dry matter yield and water-use efficiency without adversely affecting root mass when interval between harvest events averaged 32 to 35 days.

Key Words: Eragrostis curvula (Shrad.) Nees, root mass, wateruse efificiency, crude protein

Weeping lovegrass [Eragrostis curvula (Shrad.) Nees] is a perennial, warm-season grass, native to south and central Africa. In Africa, this species occupies a niche in an intermediate seral stage where stands are maintained by disturbance (i.e., burning and heavy grazing) (Leigh 1961). Weeping lovegrass was introduced to the southwestern United States in the 1920's to control erosion of sandy soils. With development of appropriate management strategies, weeping lovegrass is now recognized as an excellent soil conservation species and a valuable source of forage. However, weeping lovegrass will become unproductive and unpalatable if improperly managed.

A management strategy that has been developed to enhance weeping lovegrass yield and quality and improve livestock performance consists of fertilization coupled with frequent, short periods of intense grazing (Dahl and Cotter 1984). Cotter et al. (1983) found that cattle gains increased by more than $250 \mathrm{~kg} / \mathrm{ha}$ on rotationally grazed weeping lovegrass. Performance increased when cattle were stocked at a rate that ensured all plants were grazed to a $10-\mathrm{cm}$ stubble height within 2 to 5 days. Shoop et al.

\footnotetext{
At the time of research, authors were graduate research assistant and associate professor, Departmem of Ranaf -

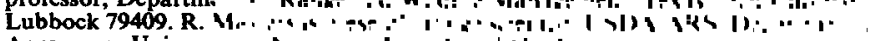

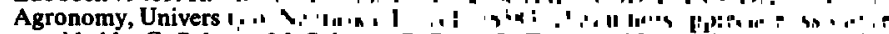
provided by G. Salazar, M. Salazar, G. Scott, L. Tello, and M. De Lo Santos during the project leading to this manuscript. This study is a contribution of the College of Agricultural Sciences, Texas Tech University, T-9-579.

Manuscript accepted 12 March 1990.
}

(1976) considered a pasture ready for grazing when weeping lovegrass regrowth was between 30 and $40 \mathrm{~cm}$ tall and recommended that pasture rest periods not exceed $\mathbf{4 0}$ days.

Evaluation of this forage management strategy has focused on animal weight gains and herbage yield and quality. Information on the influence of clipping, fertilization, and variations in water availability on root mass and water-use efficiency is needed to more completely assess management efficacy. Therefore, the objective of this study was to determine how clipping, fertilization, and frequency of watering influence herbage dry matter yield, crude protein yield, water-use efficiency, and root mass of individual 'Ermelo' weeping lovegrass plants.

\section{Methods}

This experiment was designed to simulate the short duration grazing strategy outlined by Dahl and Cotter (1984) to improve weeping lovegrass quantity, quality, and utilization by livestock. To assess root mass response to clipping, fertilization, and watering, treatments were imposed on containerized weeping lovegrass growing in a field environment. Clipping was deemed an appropriate method to simulate the rapid removal of forage by livestock in a short duration grazing program.

During the fall of 1981,342 polyethylene tubes $(25 \mathrm{~cm}$ diam $\times 60$ $\mathrm{cm}$ length) were sealed at one end and filled with $40 \mathrm{~kg}$ of Amarillo fine sandy loam soil (fine, loamy, mixed thermic Aridic Paleustalf). The tubes were buried, with open ends exposed, in holes $(60 \mathrm{~cm}$ deep and $35 \mathrm{~cm}$ diam) excavated in a native shortgrass prairie located in Lubbock, Texas. On 4 June 1982, about 25 caryopses of Ermelo weeping lovegrass were planted in each tube. At the 4-leaf growth stage, weeping lovegrass seedlings were thinned to 4 per tube. Plants were uniformly watered every 14 days throughout the summer and early fall of 1982.

On 28 April 1983 all plants were clipped to a 10-cm stubble height. At this time, 20 tubes were excavated to determine aboveground and belowground plant mass before treatment. Plants were removed from the tubes, placed on a $0.5 \mathrm{~mm}$ mesh screen, and the soil was washed from the roots. Washed plants were oven-dried, stubble and roots were separated, and weighed. On 29 April 1983, 168 randomly selected tubes were each fertilized (F) with $3.8 \mathrm{~g}$ $\mathrm{NH}_{4} \mathrm{NO}_{3}$ and $3.0 \mathrm{~g} \mathrm{KH}_{2} \mathrm{PO}_{4}$, comparable to a broadcast fertilizer application of 70-34-44 kg N-P-K/ha.

Watering treatments started on 12 May 1983 and ended 22 October 1983. Ninety-eight of the fertilized tubes and 84 unfertilized tubes were watered to field capacity $(-0.01 \mathrm{MPa})$ every 7 days (WET) while remaining tubes were watered to field capacity at 14-day intervals (DRY). Soil samples were collected from 4 tubes per treatment combination $24 \mathrm{hr}$ before each watering event, oven dried at $105^{\circ} \mathrm{C}$, and weighed. Volume of water to be applied was determined by comparing the average water content of the soil within the tubes with a water retention curve developed from the soil. To lessen disturbance caused by soil removal, only 2 cores (25-cm length $\times 19-\mathrm{mm}$ diam) were taken from any tube during the experiment. Soil removed during sampling was replaced with oven dried loamy sand that had been passed through a $0.5 \mathrm{~mm}$ mesh screen. 


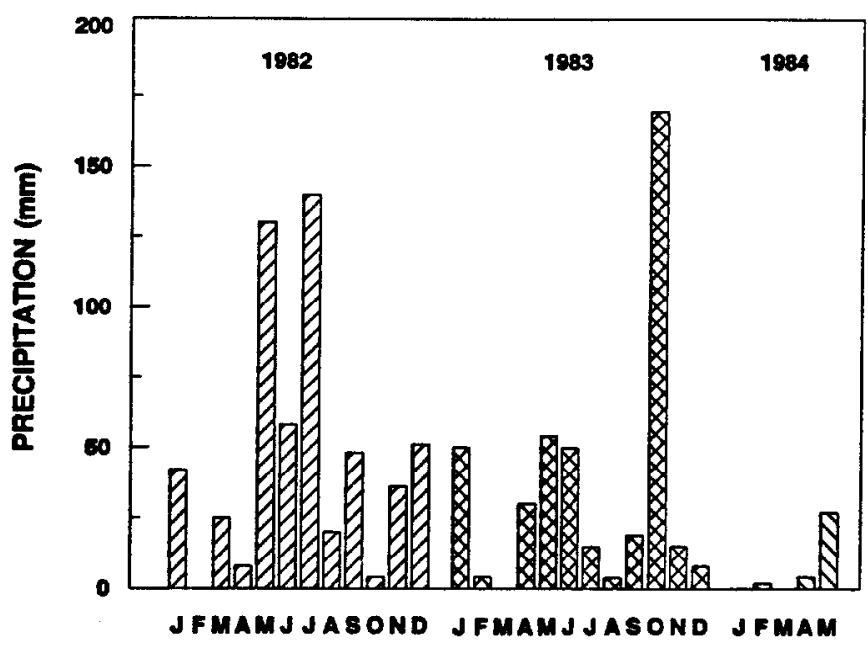

MONTH

Fig. 1. Monthly precipitation occurring at the Lubbock study site from 1982 through 1984.

Clipping treatments occurred between 29 April and 15 September 1983. Half the weeping lovegrass within each fertilization by watering frequency treatment combination were clipped $(C)$ to a 10 -cm stubble height when regrowth height reached $40 \mathrm{~cm}$. At each herbage harvest, 7 tubes containing clipped plants were randomly selected and excavated. Another 7 tubes containing similarly fertilized and watered plants that had not been clipped were randomly selected, herbage removed to a $10-\mathrm{cm}$ stubble height, and excavated. Excavated plants were washed and prepared as indicated above. The herbage (aboveground plant portion less the stubble) was oven dried at $60^{\circ} \mathrm{C}$ for $48 \mathrm{hr}$, and weighed. Herbage samples were ground in a Wiley mill and analyzed for crude protein content (CP) using the microkjeldahl procedure to determine nitrogen (N) content $(\mathrm{CP}=\% \mathrm{~N} \times 6.25)$ (Anonymous 1960). In anticipation that WET-F-and WET-treated plants would grow more rapidly and be harvested more frequently than DRY-F- or DRY-treated plants, more tubes were allocated to the WET-F and WET treatments to ensure that a sufficient number were available for excavation at each harvest date.

The experiment was arranged as a $2^{3}$ factorial (2 levels of each of the 3 factors: clipping, fertilization, and watering frequency) in a completely random design. A final harvest and excavation of plants within 7 tubes per treatment combination occurred at the end of the experiment on 15 March 1984. Therefore, analysis of variance procedure for a factorial experiment was used to evaluate cumulative herbage dry matter yield, crude protein yield, and water-use efficiency over the period of the experiment and root mass present at the end of the experiment. Treatment means were compared at the 0.05 level of probability using Tukey's $w$ procedure (Ott 1977).

Cumulative herbage dry matter yield was obtained for clipped plants by summing amount of harvested herbage obtained at each sampling date and for unclipped plants by summing the net increase in yield across consecutive herbage harvest events. Cumulative crude protein yield was calculated by multiplying the crude protein content of the herbage by the herbage dry matter yield at each sampling date and summed across sampling dates. Cumulative water-use efficiency of the herbage was calculated by dividing the cumulative herbage dry matter yield by volume of water added during the growing season less the volume of water remaining in the soil at the end of the growing season (22 October 1983). Volume of water added to the tubes was determined by
Table 1. Mean cumulative herbage dry matter yield, crude protein yield, and water-use efflency (WUE) and root mass of individual 'Ermelo' weeping lovegrass plants growing in an experiment conducted from 28 April 1983 to 15 March 1984 in Lubbock, Texas.!

\begin{tabular}{|c|c|c|c|c|}
\hline Treatment $^{2}$ & $\begin{array}{c}\text { Dry } \\
\text { matter }\end{array}$ & $\begin{array}{c}\text { Crude } \\
\text { protein }\end{array}$ & Root & WUE \\
\hline WET & \multicolumn{3}{|c|}{$\ldots-\ldots+$ g/tube $\ldots \ldots \ldots$} & $-\mathrm{g} D M / 1^{3}-$ \\
\hline $\begin{array}{l}\text { F-C } \\
\text { F } \\
C \\
O\end{array}$ & $\begin{array}{l}79.0 \\
43.9 \\
41.0 \\
44.7\end{array}$ & $\begin{array}{l}7.8 \\
6.4 \\
2.2 \\
1.4\end{array}$ & $\begin{array}{l}19.1 \\
34.4 \\
20.2 \\
26.7\end{array}$ & $\begin{array}{l}0.8 \\
0.4 \\
0.4 \\
0.4\end{array}$ \\
\hline \multicolumn{5}{|l|}{ DRY } \\
\hline $\begin{array}{c}\text { F-C } \\
\text { F } \\
\text { C } \\
\text { O } \\
\text { Tukey }(0.05)^{4}\end{array}$ & $\begin{array}{l}55.9 \\
32.1 \\
35.6 \\
28.2 \\
14.4\end{array}$ & $\begin{array}{l}6.2 \\
4.7 \\
1.6 \\
1.5 \\
\text { NS }\end{array}$ & $\begin{array}{r}18.7 \\
21.2 \\
19.4 \\
25.4 \\
9.4\end{array}$ & $\begin{array}{l}0.7 \\
0.4 \\
0.5 \\
0.4 \\
\text { NS }\end{array}$ \\
\hline \multicolumn{5}{|c|}{ Analyses of Variance } \\
\hline $\begin{array}{lr}\text { Source } & \text { df } \\
\text { Fertilize (F) } & 1 \\
\text { Water (W) } & 1 \\
\text { Clip (C) } & 1 \\
\text { F X W } & 1 \\
\text { F } \times C & 1 \\
\text { W } \times C & 1 \\
\text { F } \times \text { W } \times C & 1\end{array}$ & $\begin{array}{l}\text { F- } \\
0.01 \\
0.01 \\
0.01 \\
0.16 \\
0.01 \\
0.97 \\
0.02\end{array}$ & $\begin{array}{c}\text { Probabili } \\
0.01 \\
0.01 \\
0.01 \\
0.01 \\
0.01 \\
0.37 \\
0.10\end{array}$ & $\begin{array}{l}0.77 \\
0.01 \\
0.01 \\
0.06 \\
0.38 \\
0.03 \\
0.04\end{array}$ & $\begin{array}{l}0.01 \\
0.18 \\
0.01 \\
0.05 \\
0.01 \\
0.83 \\
0.17\end{array}$ \\
\hline $\mathrm{F} \times \mathrm{W} \times \mathbf{C}$ & \multicolumn{3}{|c|}{ Sums of Squares } & \\
\hline Error & 3415 & 11.4 & 1462 & 0.22 \\
\hline
\end{tabular}

'Herbage dry matter yield, crude protein yield, and water-use efficiency are cumulative values obtained over the period of 28 April 1983 to 15 March 1984 and root mass values were obtained on 15 March 1984.

${ }^{2}$ Treatments are; $F=$ fertilized (equivalent to broadcast application of $70-34-44 \mathrm{~kg}$ N-P-K/ha), WET = watered cvery 7 days, DRY = watered every 14 days, and $\mathrm{C}=$ herbage clipped to a $10 \mathrm{~cm}$ stubble height when regrowth reached $40 \mathrm{~cm}$, and $0=$ no fertilizer or clipping treatment.

${ }^{3}$ Water use efficiency is expressed as grams (g) of dry matter (DM) per liter (1) of water applied.

${ }^{4}$ Critical values for comparison of treatment means obtained using Iukey's wProcedure where $P \geq 0.05$ and $\mathrm{df}=40$.

summing the volumes added during watering and naturally occurring precipitation events (Fig. 1).

Comparisons of cumulative aboveground weight (stubble and herbage combined) and root mass at each sampling date during the growing season were made between clipped and unclipped plants within fertilization and watering treatment combinations using Student's $t$-test (Ott 1977). Cumulative aboveground weight was obtained by combining cumulative herbage and stubble dry matter yield estimates at each harvest date. Cumulative stubble yield was determined for plants by summing the net increase in stubble yield from 1 harvest event to the next.

\section{Results and Discussion}

Weeping lovegrass herbage and aboveground yield were enhanced by clipping, fertilization, and frequent watering. Within watering treatments, herbage yield of fertilized and clipped plants was greater than that of other plants (Table 1). From May to September 1983, WET-F-treated plants produced sufficient regrowth for 6 herbage harvest events while remaining plants were only harvested 4 times (Fig. 2). Clipping enhanced cumulative aboveground yield of WET-F-treated weeping lovegrass. At every sampling date after 1 June 1983, cumulative yield of clipped WETF-treated plants exceeded that of unclipped WET-F-treated plants.

The positive response of weeping lovegrass to clipping, fertilization, and irrigation was expected. Clipping at the proper intensity and frequency can improve warm-season grass productivity (Younger 

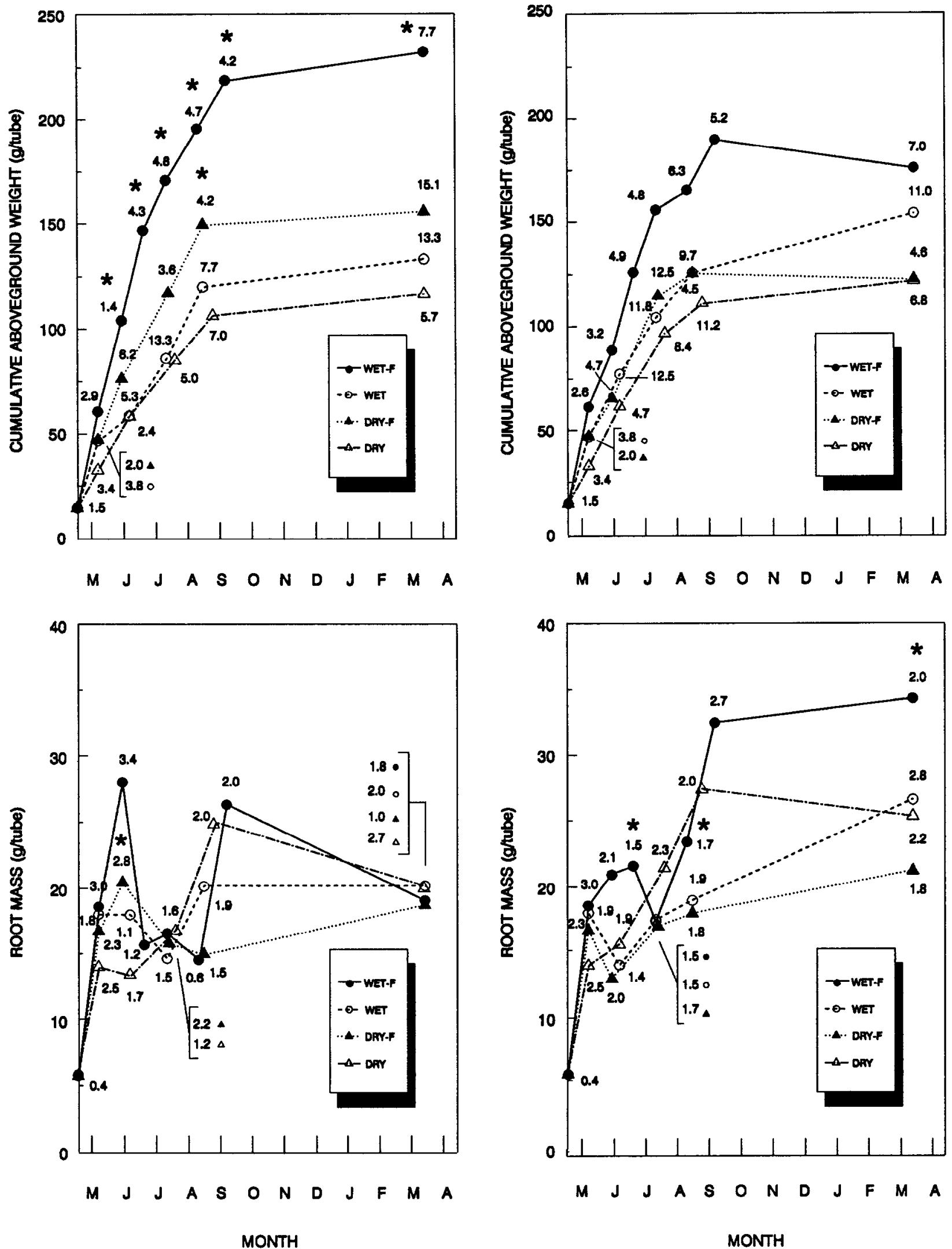

Fig. 2. Cumulative abovezround (stubble and herbage) and mean root mass of clipped and unclipped weeping lovezrass from 28 April 1983 to 15 March 1984. Clipped plants were harvested to $10-\mathrm{cm}$ stubble height each time regrowth reached $40 \mathrm{~cm}$. The * indicates that the weight of the plant portion is significantly greater $(P \geq 0.05)$ according to Student's $t$-test and enables comparisons between clipped and unclipped plants at each sampling date within fertilization and watering frequency treatments. Number associated with each point is the standard error of the treatment mean. Treatments are; $F=$ fertilized (equivalent to broadcast application of 70-34-44 kg N-P-K/ha), WET = watered every 7 days, and DRY = watered every 14 days. 
1972, Crider 1955). Jameson (1963) reported that defoliation improved grass yields by increasing tiller number and replacing mature leaves with younger, more photosynthetically efficient leaves. Fertilization and irrigation increased forage yields by alleviating nutrient and water deficiencies that limited growth (Power 1983, Wight and Black 1979).

Fertilization increased cumulative crude protein yield of weeping lovegrass herbage (Table 1). Whether averaged across clipping or watering regimes, fertilized plants yielded at least $5.4 \mathrm{~g}$ crude protein/tube as compared to less than $2.0 \mathrm{~g}$ crude protein/tube produced by unfertilized plants. The crude protein yield values represent both herbage dry matter yield and crude protein content. Therefore, the increase in crude protein yield caused by fertilization coupled with either clipping or frequent watering reflects the positive response of herbage dry matter yield to these treatments.

Based on samples obtained at the end of the experiment (15 March 1984), root mass of WET-, DRY-F-, and DRY-treated plants was not adversely affected by clipping (Table 1). In contrast, root mass of WET-F-treated weeping lovegrass was significantly reduced by $44 \%$ following frequent clipping during the growing season. Potential consequences of such a root mass decline include reduced plant productivity and survival. Reduction of root mass caused by clipping was found to decrease grass tolerance to drought (Weaver and Albertson 1943, Crider 1955) and competitive ability (Weaver 1930).

Frequency of herbage harvest and average time interval between harvests may explain the observed decline in root mass of WET-Ftreated weeping lovegrass as compared to WET-, DRY-F-, and DRY-treated plants (Fig. 2). The time interval between clipping events occurring after 1 June was relatively short (average of 24 days) and may not have been of sufficient length for plants to recuperate from clipping. In contrast, WET-, DRY-F, and DRYtreated plants were only harvested 3 times and average clipping intervals after $1 \mathrm{June}$ were 32,32 , and 35 days, respectively. This supports Younger (1972), who reported root mass reduction of selected grasses increased with defoliation frequency.

The WET-F treatment simulates optimum growing conditions, when nutrients and water are available throughout the growing season, which rarely occur on sandy pastures in the southern Great Plains. Under typical pasture conditions it is unlikely that weeping lovegrass would provide sufficient regrowth for 6 harvests during a single growing season. In contrast, the DRY treatment, where water was provided less frequently, probably approximates field conditions more closely than the WET treatment.

Decreases in root mass of WET-F-C-treated plants during early to mid-summer may result from root death caused by defoliation (Fig. 2). In this study, root mortality was not quantified because of the difficulty in separating live and dead roots. However, loss of dead and decomposing roots during washing procedures could account for observed reductions in root mass. Others have determined that root mortality increased following frequent and severe defoliation (Harradine and Whalley 1981, Hodgkinson and Baas Becking 1977).

Weeping lovegrass root and shoot growth occurred concurrently from May through early June, regardless of clipping (Fig. 2). However, depending on treatment, root growth slowed or root mass actually declined during July and increased through late August into September. Despite confinement of weeping lovegrass roots in a relatively small volume (about 30 liters), the pattern of root growth generally agreed with root studies conducted by Shoop (1977) in a rhizotron containing a much larger soil volume. Additional comparisons regarding weeping lovegrass response to defoliation between this and Shoop's (1977) experiments are difficult to make because of differences in clipping heights and frequen- cies and methods used to measure root growth.

Clipped and fertilized weeping lovegrass were about twice as water-use efficient as unclipped or unfertilized plants (Table 1). This improvement in water-use efficiency may result from maintenance of young leaf tissue by clipping and alleviation of nutrient deficiencies by fertilization. Clipping reduced the proportion of old to young leaves and improved water-use efficiency by removing less efficient old leaves and replacing them with young regrowth (Larcher 1980). Power (1983) indicated that fertilization affected water-use efficiency by correcting nutrient deficiencies that restricted plant growth and yield.

Clipping influenced 2 factors that affected plant water-use efficiency; leaf age and leaf surface area. With advanced age, weeping lovegrass leaves were probably less water-use efficient because of a diminished capacity to adjust stomatal openings to control water loss. Water-stressed corn and sorghum at the vegetative stage of growth were able to close stomates, while stomates remained open when the same stress was applied to more mature plants at the reproductive stage of growth (Ackerson and Krieg 1977).

Reduction in leaf surface area following clipping could have enhanced weeping lovegrass water status. In other studies, topgrowth removal improved plant water potential by reducing transpiring leaf surface of selected grasses (Wolf and Parish 1982, Svejcar and Christiansen 1987). These authors indicated that reducing transpiring surface area enabled plants to maintain a positive water balance and overcome limitations to growth caused by an inadequate root system or low soil water availability.

\section{Summary}

This study was conducted to determine the response of individual weeping lovegrass plants to a management strategy developed to improve plant yield and quality. The treatments had a positive effect on herbage yield and water-use efficiency. Clipping at the frequency and intensity specified by Dahl and Cotter (1984) reduced root mass of WET-F-treated plants. The WET-F treatment simulates conditions which rarely occur in the southern Great Plains. Based on this simulation of a forage management strategy periodic harvest of weeping lovegrass combined with fertilization improved forage quality and quantity without adversely affecting root mass if the intervals between harvest events averaged 32 to 35 days.

\section{Literature Cited}

Ackerson, R.C., and D.R. Krieg. 1977. Stomatal and nonstomatal regulation of water use in cotton, corn, and sorghum. Plant Physiol. 65:455-459.

Anonymous. 1960. Official methods of analysis. (9th ed.) Assoc. Off. Agr. Chem. Washington, D.C.

Cotter, P.F., B.E. Dahl, and G. Scott. 1983. Utilization of a short duration grazing system for renovation and management of weeping lovegrass (Eragrostis curvula) in the Rolling Plains of Texas. p. 24-30. In: Proc. Forage and Grassl. Conf., Amer. Forage and Grassl. Counc. Lexington, Ky.

Crider, F.S. 1955. Root growth stoppage resulting from defoliation of grass. USDA Tech. Bull. 1102.

Dahl, B.E., and P.F. Cotter. 1984. Management of weeping lovegrass in west Texas. Texas Tech Univ. Dept. Range and Wildl. Manage. Note 5. Texas Tech Press, Lubbock.

Harradine, A.R., and R.D.B. Whalley. 1981. A comparison of the root growth, root morphology and root response to defoliation of Aristida ramosa R. Br. and Danthonia linkii Kunth. Aust. J. Agr. Res. 32:565-574.

Hodgkinson, K.C., and H.G. Baas Becking. 1977. Effect of defoliation on root growth of some arid zone perennial plants. Aust. J. Agr. Res. 29:31-42.

Jameson, D.A. 1963. Response of individual plants to harvesting. Bot. Rev. 27:532-594. 
Larcher, W. 1984. Physiological plant ecology. Springer-Verlag. Berlin. Leigh, J.H. 1961. Persistence of some varieties of pasture grass and their susceptibility to invasion by other species. J. Ecol. 49:341-345.

Ott, L. 1977. An introduction to statistical methods and data analysis. Duxberry Press, Belmont, Calif.

Power, J.F. 1983. Soil management for efficient water use: Soil fertility. p. 471-470. In: Limitations to efficient water use in crop production. H.M. Taylor, W.R. Jordan, and T.B. Sinclair (ed.). Amer. Soc. Agron. Madison, Wisc.

Shoop, M.C. 1977. Foliage and root growth of weeping lovegrass. Ph.D. Diss. Colorado State Univ. Boulder.

Shoop, M.C., E.H. McIlvain, and P.W. Voight. 1976. Morpa weeping lovegrass produces more beef. J. Range Manage. 29:101-103.

Svejcar, T., and S. Christiansen. 1987. Grazing effects on water relations of caucasian bluestem. J. Range Manage. 40:15-18.
Weaver, J.E. 1930. Underground plant development in its relation to grazing. Ecology 11:543-557.

Weaver, J.E., and F.W. Albertson. 1943. Resurvey of grasses, forbs, and underground plant parts at the end of the great drought. Ecol. Monogr. 13:64-117.

Wight, J.R., and A.L. Black. 1979. Range fertilization: Plant response and water use. J. Range Manage. 32:345-349.

Wolf, D.D., and D.J. Parish. 1982. Short term growth responses of tall fescue to changes in soil water potential and to defoliation. Crop Sci. 22:996-999.

Younger, V.B. 1972. Physiology of defoliation and regrowth, p. 292-302. In:V.B. Younger and C.M. McKell (eds.), Biology and utilization of grasses. Acad. Press, New York.

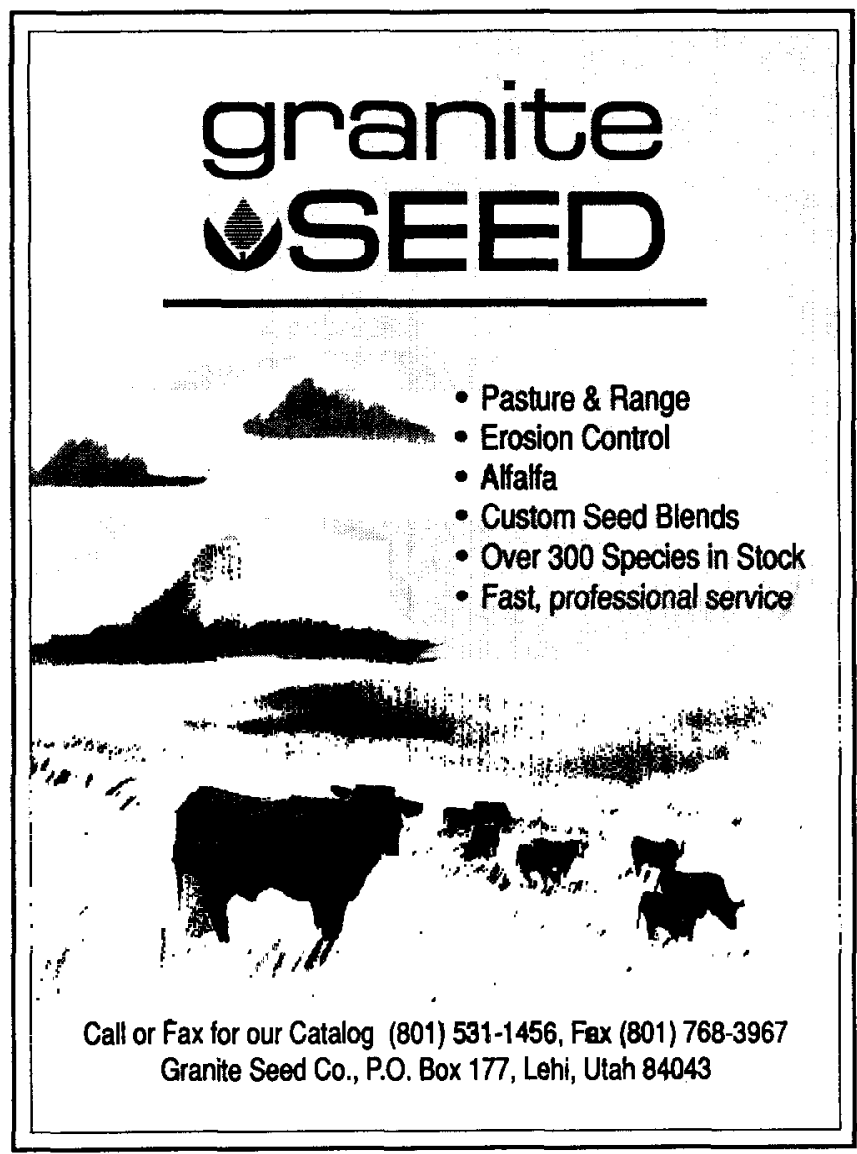

